\title{
Prevalence of visual impairment, blindness, ocular disorders and cataract surgery outcomes in low-income elderly from a metropolitan region of São Paulo - Brazil
}

\author{
Prevalência de cegueira, deficiência visual e alteraçôes oculares numa \\ população idosa e de baixa renda na cidade de São Paulo
}

\author{
Arnaud Araújo Filho ${ }^{1}$ \\ Solange Rios Salomão \\ Adriana Berezovsky ${ }^{3}$ \\ Rafael Werneck Cinoto ${ }^{4}$ \\ Paulo Henrique Ávila Morales ${ }^{5}$ \\ Francisco Roberto Gonçalves Santos ${ }^{6}$ \\ Rubens Belfort Jr.7
}

\begin{tabular}{|c|}
\hline ABSTRACT \\
\hline 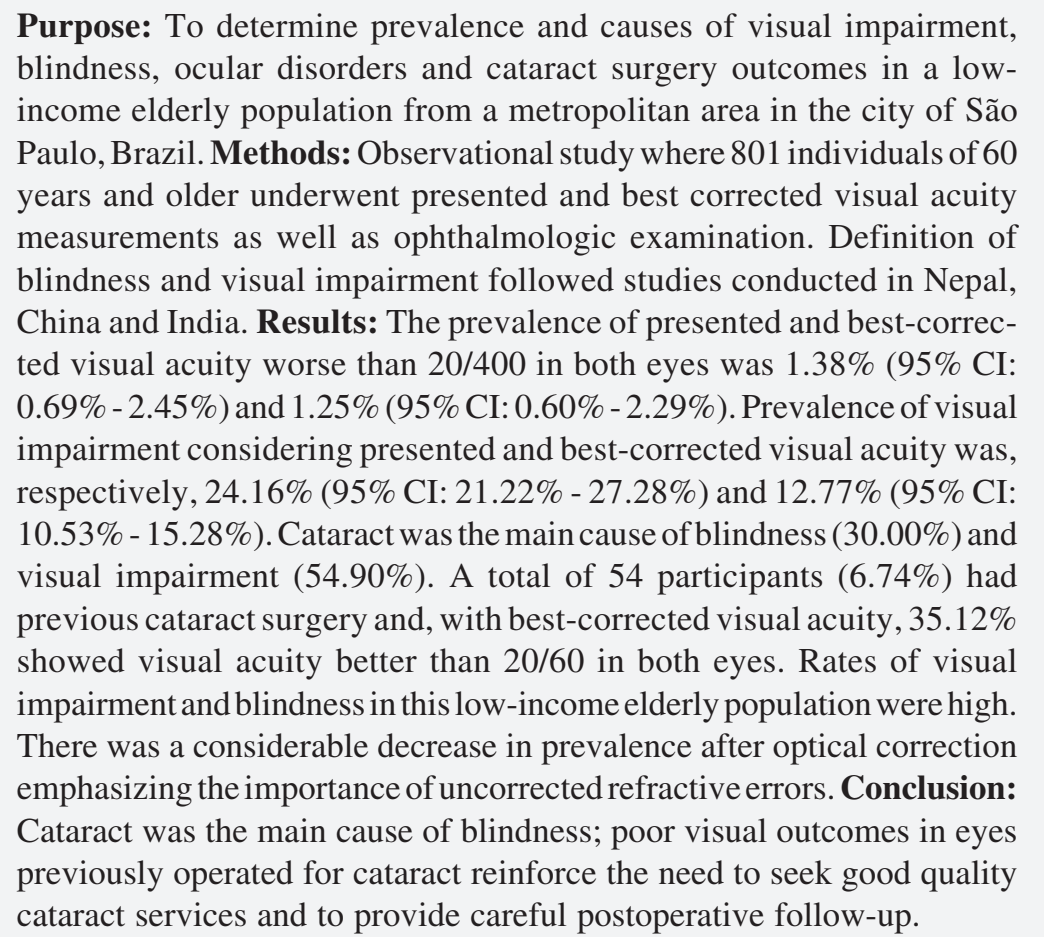 \\
\hline
\end{tabular}

Keywords: Blindness/epidemiology; Visual disorders/epidemiology; Refractive errors/epidemiology; Cataract/epidemiology; Aged; Brazil

\section{INTRODUCTION}

The latest estimates of the World Health Organization (WHO) indicate that there are 161 million visually impaired people worldwide, 37 million of which are blind, with a yearly increase of 1 to 2 million - this means approximately $0.85 \%$ of the world population. Another 135 million show visual impairment $^{(1)}$. Prevalence of blindness increases with age, mainly after 50, being higher in rural areas and among women, probably because of their socioeconomical vulnerability, as well as the obstacles they face to access health services ${ }^{(2)}$. 
The number of individuals aged 60 years and over is rapidly increasing, coinciding with a massive urbanization and quick decline of mortality and fertility rates. According to recent estimates, by the year 2025, Brazil will show the sixth largest concentration of elderly in the world, over 32 million, representing almost $13 \%$ of the Brazilian population ${ }^{(3)}$.

The impact of visual loss on the personal, economic and social life is profound. Population-based research has shown that at a best-corrected visual acuity (BCVA) 20/60 or less, $85 \%$ of people aged 65 and over cannot read standard newspaper effectively (they read less than 80 words per minute). Among people with a BCVA less than 20/100, 87\% have significant difficulty recognizing faces. At 20/200, over $50 \%$ of people have difficulty with mobility, and over $66 \%$ have difficulty with simple tasks such as dialing a phone number, or using a key or plug correctly ${ }^{(4)}$.

In a recent estimate of the World Health Organization (WHO), Brazil was included in a subregion along with Barbados and Paraguay, where the estimate of blindness prevalence in individuals over 50 years old was $1.3 \%$, representing almost a million people ${ }^{(1)}$. Table 1 shows several recent studies around the world on the prevalence of visual impairment and blindness, as well as the major causes and the parameters used to define them in populations with 40 years and older.

Cataract is the main cause for $47.8 \%$ of blindness in the world. Cataract surgery is considered one of the most costeffective intervention to restore sight ${ }^{(5)}$. Glaucoma $(12.3 \%)$, age-related macular degeneration (AMD) $(8.7 \%)$, corneal opacities $(5.1 \%)$ and diabetic retinopathy $(4.8 \%)$ are also important causes of blindness, besides childhood blindness $(3.9 \%)$, trachoma $(3.6 \%)$ and onchocercosis $(0.8 \%)^{(1-2,4)}$.

Refractive errors were not considered an important blindness cause since most studies used best-corrected visual acuity (VA) for distance as their main outcome measure. However, in 1999, WHO has recommended the elimination of this condition of reversible blindness and has included it as a priority in the "Vision 2020 Project - Right to Sight"(6-7).

In Brazil, there is a large variation in the rates of blindness and visual impairment. The rates range from $0.1 \%$ to $6.8 \%$, and there is no standardization of the criteria used for blindness and visual impairment definition. The major causes of blindness and visual impairment were cataract and uncorrected refractive errors ${ }^{(8-9)}$.

Scarcity of ocular epidemiological data in Brazilian metropolitan areas ${ }^{(1,10-12)}$, associated with the interest of the Department of Science, Technology, Tourism and Economical Development of the State of São Paulo [DSTTED] in obtaining health data about the elderly, encouraged the development of an epidemiological study by the Reference Center for the Elderly - RCE (Centro de Referência do Idoso-CRI), an entity of the Health Department of the State of São Paulo. RCE action area comprehends approximately $24 \mathrm{~km}^{2}$ of the metropolitan region of São Paulo East Zone 2, called São Miguel Paulista, consisting of 5 districts: Ermelino Matarazzo, Itaim Paulista, São Miguel, Vila Curuçá, and Vila Jacuí.
According to the Brazilian Census of the year 2000, the total number of elderly in that area was 43,721 individuals, $58 \%$ female and $42 \%$ male $^{(13)}$. It is a high demographic density zone, with a total of 705,385 inhabitants. In that area, $11.6 \%$ of the heads of households have no income at all, $10.2 \%$ have income between $>0$ and 1 current minimum wage (MW); $32.4 \%$ between $>1$ e $3 \mathrm{MW} ; 21.0 \%$ between $>3$ and $5 \mathrm{MW} ; 18.5$ between $>5$ and $10 \mathrm{MW} ; 5.1 \%$ between $>10$ and $20 \mathrm{MW}$ and only $1.2 \%$ with income above $20 \mathrm{MW}$ per household $^{(14)}$.

The purpose of the present study was to determine the prevalence of blindness, visual impairment and their respective causes, and the frequency of ocular disorders, as well as cataract surgery outcomes in a sample of the low-income elderly population living in São Miguel Paulista region, in the city of São Paulo, Brazil.

\section{METHODS}

\section{Participants}

This cross-sectional study was conducted from April to July 2002 in the facilities of the RCE, and was approved by UNIFESP's Ethics in Research Committee.

Participants were 801 individuals with 60 to 90 years of age (mean: $69.0 \pm 6.1 \mathrm{yrs} ; 206$ men and 595 women) and the study sample was obtained in two stages: $34.5 \%$ of the individuals were drawn from lists supplied by senior groups in the area, and $65.5 \%$ through active search in RCE's appointment schedule. The criteria for inclusion were the signature on the informed consent form and the age $\geq 60$ at the date of the ophthalmologic examination.

Table 2 shows age and gender distribution of the 801 participants. Most of them were females (74.28\%) and $60.42 \%$ were less than 70 years old.

\section{Procedures}

Examinations were taken at RCE's facilities where eight workstations were installed. The field team consisted of the following members: 6 experienced ophthalmologists (MD), 4 ophthalmic technologists, 7 ophthalmic technology undergraduate students, 1 psychologist, 1 nurse, 3 nurse's aides, 2 research assistants, 2 logistics assistants, 5 administrative assistants, 2 volunteers (from senior groups), 10 volunteers (Lions Club), 2 medical coordinators, 1 research coordinator and 1 general coordinator.

The following procedures were applied to all participants: Presented visual acuity (VA) measurement: monocular with or without glasses, according to what the patient was wearing at the time of the examination. For distance VA, a printed tumbling " $E$ " optotype chart was used at five meters, and for near VA, Jaeger's tumbling "E" optotype chart was used at $40 \mathrm{~cm}$, both with adequate light conditions. Computerized refractometry: refractive errors were evaluated by an automated system. Refractometry: Best-corrected 
248 Prevalence of visual impairment, blindness, ocular disorders and cataract surgery outcomes in low-income elderly from a metropolitan region of São Paulo - Brazil

\begin{tabular}{|c|c|c|c|c|c|c|c|}
\hline Country & Studies & $\mathbf{N}$ & $\begin{array}{l}\text { Age } \\
\text { (yrs) }\end{array}$ & & $\begin{array}{l}\text { VA } \\
\text { teria }\end{array}$ & Type & $\begin{array}{l}\text { Vis imp } \\
\text { prev }\end{array}$ \\
\hline \multirow[t]{2}{*}{ Austrália } & Blue mountains (1996) ${ }^{(25)}$ & 3647 & $\geq 49$ & $\leq 20 / 40-$ & \multirow[t]{2}{*}{$->20 / 160$} & BCVA & $4.00 \%$ \\
\hline & Visual Impairment Project $(1996)^{(35)}$ & 4744 & $\geq 40$ & $<20 / 60$ & & BCVA & $1.34 \%$ \\
\hline Brazil & $\begin{array}{l}\text { Esteves et al. }(1996)^{(8)} \\
\text { Arieta et al. }(2003)^{(8)}\end{array}$ & $\begin{array}{r}1369 \\
60404\end{array}$ & $\begin{array}{l}0 \text { a } 94 \\
\geq 50\end{array}$ & $\leq 20 / 100^{-}$ & $0^{-}$ & $\mathrm{PA}^{-}$ & $\begin{array}{c}- \\
18.97 \%\end{array}$ \\
\hline Caribbean & Barbados Eye Study (1997) ${ }^{(34)}$ & 4631 & $40-84$ & $20 / 60-$ & - $20 / 400$ & BCVA & $5.70 \%$ \\
\hline China & $\begin{array}{l}\text { Zhao et al. }(1998)^{(17)} \\
\text { Michon et al. }(2002)^{(18)}\end{array}$ & $\begin{array}{l}5052 \\
3441\end{array}$ & $\begin{array}{l}\geq 50 \\
\geq 60\end{array}$ & $\begin{array}{l}<20 / 60- \\
<20 / 60-\end{array}$ & $\begin{array}{l}-\quad 20 / 400 \\
-\quad 20 / 400\end{array}$ & $\begin{array}{l}\text { PA } \\
\text { PA }\end{array}$ & $\begin{array}{l}25.75 \% \\
31.60 \%\end{array}$ \\
\hline Denmark & Copenhagen Eye Study $(2001)^{(27)}$ & 946 & $60-80$ & $<20 / 60-$ & $-20 / 400$ & BCVA & $1.58 \%$ \\
\hline EUA & $\begin{array}{l}\text { SEE project (Salisbury) }(2000)^{(24)} \\
\text { Proyecto Ver }(2002)^{(36)} \\
\text { LALES }(2004)^{(26)}\end{array}$ & $\begin{array}{l}2520 \\
4774 \\
6357\end{array}$ & $\begin{array}{l}65-84 \\
\geq 40 \\
\geq 40\end{array}$ & $\begin{array}{l}<20 / 40- \\
<20 / 40- \\
\leq 20 / 40-\end{array}$ & $\begin{array}{l}->20 / 200 \\
->20 / 200 \\
-\quad 20 / 160\end{array}$ & $\begin{array}{l}\text { BCVA } \\
\text { BCVA } \\
\text { BCVA }\end{array}$ & $\begin{array}{l}3.37 \% \\
1.92 \% \\
3.00 \%\end{array}$ \\
\hline The Netherland & Rotterdam Study (1998) $)^{(33)}$ & 6775 & $\geq 50$ & $<20 / 60-$ & $-20 / 400$ & BCVA & $1.44 \%$ \\
\hline India & $\begin{array}{l}\text { Murthy et al. }(2001)^{(23)} \\
\text { Nirmalan et al. }(2002)^{(21)} \\
\text { Aravind Eye Study }(2003)^{(37)}\end{array}$ & $\begin{array}{l}4284 \\
5411 \\
5150\end{array}$ & $\begin{array}{l}\geq 50 \\
\geq 50 \\
\geq 40\end{array}$ & $\begin{array}{l}<20 / 60- \\
<20 / 60- \\
<20 / 60-\end{array}$ & $\begin{array}{l}-\quad 20 / 400 \\
-\quad 20 / 400 \\
-\quad 20 / 400\end{array}$ & $\begin{array}{l}\text { BCVA } \\
\text { BCVA } \\
\text { MC }\end{array}$ & $\begin{array}{l}10.20 \% \\
10.10 \% \\
13.40 \%\end{array}$ \\
\hline Nepal & Phokarel et al. $(1998)^{(20)}$ & 4602 & $\geq 45$ & $<20 / 60-$ & - $20 / 400$ & BCVA & $6.10 \%$ \\
\hline Paraguay & Duerksen et al. $(2004)^{(19)}$ & 2136 & $\geq 50$ & $<20 / 200$ & & PA & $10.74 \%$ \\
\hline Taiwan & Shihpai Eye Study (2004)(38) & 1361 & $\geq 65$ & $<20 / 60-$ & - $20 / 400$ & BCVA & $2.94 \%$ \\
\hline
\end{tabular}

\begin{tabular}{|c|c|c|c|c|c|}
\hline Country & Main causes of visual impairment & Type & $\begin{array}{l}\text { VA } \\
\text { criteria }\end{array}$ & $\begin{array}{l}\text { Blindness } \\
\text { prevalence }\end{array}$ & Main causes of blindness \\
\hline Austrália & $\begin{array}{l}\text { Cataract, AMD and glaucoma } \\
\text { Refractive error, AMD }\end{array}$ & $\begin{array}{l}\text { BCVA } \\
\text { BCVA }\end{array}$ & $\begin{array}{l}\leq 20 / 200 \\
\leq 20 / 200\end{array}$ & $\begin{array}{l}0.70 \% \\
0.34 \%\end{array}$ & $\begin{array}{l}\text { AMD, cataract } \\
A M D, \text { glaucoma }\end{array}$ \\
\hline Brazil & Refractive error, cataract, AMD, glaucoma & BCVA & $\begin{array}{c}<20 / 200 \\
-\end{array}$ & $\begin{array}{l}3.00 \% \\
-\end{array}$ & Cataract, scar of corioretinitis, DR \\
\hline Caribbean & - & BCVA & $<20 / 400$ & $1.70 \%$ & Cataract and glaucoma, retinal diseases \\
\hline China & $\begin{array}{l}\text { Cataract, refractive error } \\
\text { Refractive error, cataract }\end{array}$ & $\begin{array}{l}\mathrm{E} \\
\mathrm{E}\end{array}$ & $\begin{array}{l}<20 / 400 \\
<20 / 400\end{array}$ & $\begin{array}{l}1.70 \% \\
0.70 \%\end{array}$ & $\begin{array}{l}\text { Cataract, retina diseases, corneal opacities } \\
\text { Cataract, AMD, glaucoma }\end{array}$ \\
\hline Denmark & AMD, cataract, glaucoma & BCVA & $<20 / 400$ & $0.53 \%$ & AMD, glaucoma, retinitis pigmentosa \\
\hline EUA & $\begin{array}{l}\text { Cataract, } \mathrm{AMD}, \mathrm{DR} \\
\text { Cataract, } \mathrm{AMD}, \mathrm{DR}, \text { glaucoma } \\
\text { Cataract, DR, Glaucoma, AMD }\end{array}$ & $\begin{array}{l}\text { BCVA } \\
\text { BCVA } \\
\text { BCVA }\end{array}$ & $\begin{array}{l}\leq 20 / 200 \\
\leq 20 / 200 \\
\leq 20 / 200\end{array}$ & $\begin{array}{l}0.83 \% \\
0.29 \% \\
0.40 \%\end{array}$ & $\begin{array}{l}\text { AMD, optic atrophy and glaucoma/DR } \\
\text { Glaucoma, cataract, AMD/DR } \\
\text { DR, glaucoma, cataract, AMD }\end{array}$ \\
\hline The Netherland & Cataract, AMD, miopic degeneration & BCVA & $<20 / 400$ & $0.47 \%$ & AMD, glaucoma, miopic degeneration \\
\hline India & $\begin{array}{l}\text { Cataract, refractive error } \\
\text { Cataract, refractive error } \\
\text { Refractive error, cataract }\end{array}$ & $\begin{array}{l}\text { BCVA } \\
\text { BCVA } \\
\text { BCVA }\end{array}$ & $\begin{array}{l}<20 / 400 \\
<20 / 400 \\
<20 / 400\end{array}$ & $\begin{array}{l}5.10 \% \\
3.00 \% \\
1.00 \%\end{array}$ & $\begin{array}{l}\text { Cataract, refractive error, corneal infeccion } \\
\text { Cataract, refractive error, AMD } \\
\text { Cataract, glaucoma, optic atrophy }\end{array}$ \\
\hline Nepal & Refractive error, cataract & BCVA & $<20 / 400$ & $3.00 \%$ & Cataract, refractive error, trachoma \\
\hline Paraguay & Cataract & $\mathrm{E}$ & $<20 / 400$ & $3.14 \%$ & Cataract \\
\hline Taiwan & Cataract, miopic degeneration, AMD & BCVA & $<20 / 400$ & $0.59 \%$ & Cataract, AMD, high miopia \\
\hline
\end{tabular}

VA was recorded after refraction using streak retinoscopy. Biomicroscopy with slit lamp: Detailed external eye examination, anterior segment and intraocular pressure (IOP) measurement were performed. Indirect ophthalmoscopy: Retinal status, including vessels, macula and optic disc features were evaluated, and whenever necessary, fundus biomicroscopy was also performed. Management and referral: Free eyeglasses were provided by the joint program with the Brazilian Health Ministry/UNIFESP for those in need of prescription. For tertiary care a referral slip to UNIFESP was provided.

\section{Classification of vision categories}

Bilateral vision condition was reported using the following five vision categories for both presented and best-corrected VA used in previous reports ${ }^{(16-17)}$. Severe bilateral blindness: VA $<20 / 400$ in both eyes. Moderate bilateral blindness: $\mathrm{VA}<20 / 200$ in the worse eye and VA $<20 / 200$ to $\geq 20 / 400$ in the better eye. Unilateral blindness: VA $<20 / 200$ in the worse eye and VA $\geq 20 / 200$ in the better eye. Bilateral or unilateral impaired vision: $\mathrm{VA}<20 / 60$ to $\geq 20 / 200$ in the worse eye and VA $\geq 20 / 200$ in the better eye. Normal or near normal vision: $\mathrm{VA} \geq 20 / 60$ in both eyes. 


\section{RESULTS}

\section{Prevalence of visual impairment and blindness}

Table 3 shows visual impairment and blindness prevalence based on presenting and BCVA. Of the 801 examined elderly, 2 $(0.25 \%)$ did not inform the VA due to cognitive impairment. Normal or near normal vision was found in $516(64.58 \%)$ of the elderly. After optical correction, this number increased to $632(79.10 \%)$.

Eleven (1.38\%) elderly exhibited severe bilateral blindness, $8(1.00 \%)$ moderate bilateral blindness, $71(8.89 \%)$ unilateral blindness, $193(24.16 \%)$ unilateral or bilateral visual impairment. After best optical correction, these figures decreased respectively to: $10(1.25 \%), 2(0.25 \%), 53(6.63 \%)$ and $102(12.77 \%)$.

\section{Main causes of visual impairment and blindness}

Main causes of visual impairment and blindness (presenting VA and BCVA) are shown in table 4. Individuals with visual impairment or blindness may have different causes for it in each eye. These cases are represented twice - once for each cause. Taking the presented VA into consideration, the most common cause for visual impairment and unilateral blindness was uncorrected refractive error. Cataract was the main cause of visual impairment and blindness, following adequate optical correction.

Among those 11 elderly with severe bilateral blindness (presenting VA), the main causes were cataract (27.27\%) and diabetic retinopathy $(18.18 \%)$. With the best correction, among the 10 elderly who presented severe bilateral blindness, the main cause was cataract in $3(30.00 \%)$, followed by $2(20.00 \%)$ with diabetic retinopathy and $2(20.00 \%)$ with absence/disorganization of the ocular bulb. Of the 10 elderly

\begin{tabular}{|c|c|c|c|c|c|c|}
\hline \multirow{3}{*}{ Age } & \multicolumn{4}{|c|}{ Sex } & \multirow{2}{*}{\multicolumn{2}{|c|}{ Total }} \\
\hline & \multicolumn{2}{|c|}{ Female } & \multicolumn{2}{|c|}{ Male } & & \\
\hline & $\mathbf{N}$ & $\%$ & $\mathbf{N}$ & $\%$ & $\mathbf{N}$ & $\%$ \\
\hline $60-69$ & 366 & 61.51 & 118 & 57.28 & 484 & 60.42 \\
\hline $70-79$ & 197 & 33.11 & 68 & 33.01 & 265 & 33.08 \\
\hline$\geq 80$ & 32 & 5.38 & 20 & 9.71 & 52 & 6.49 \\
\hline Total & 595 & 74.28 & 206 & 25.72 & 801 & 100.00 \\
\hline
\end{tabular}

with severe bilateral blindness, $7(70.00 \%)$ were females and $3(30.00 \%)$ were included in those aged 80 or above. For both unilateral and bilateral visual impairment (presenting VA), uncorrected refractive error $(53.37 \%)$ and cataract $(45.08 \%)$ were the main causes among 193 (24.16\%) elderly.

After the best optical correction among 102 (12.77\%) elderly, the main causes were: cataract $(54.90 \%)$, refractive error $(38.24 \%)$ and retinal disorders $(25.55 \%)$. Age-related macular degeneration and diabetic retinopathy were the most common conditions in the retinal disorders category.

\section{Prevalence of ocular disorders}

Table 5 shows the frequency of ocular disorders in 1,602 eyes of the 801 participants. Uncorrected refractive error was the most prevalent, affecting 1,138 eyes $(71.04 \%)$, followed by cataract in $253(15.79 \%)$, retinal disorders (5.99\%) and glaucoma in $20(1.25 \%)$.

\section{Tertiary care at UNIFESP's Vision Institute}

The main reasons for tertiary referral of the $223(27.84 \%)$ elderly to the Institute of Vision are shown in table 6. Elderly who needed referrals could have different causes of visual impairment in each eye. These cases were represented twice once for each cause. Considering BCVA, cataract surgery was the main reason of referral in $77(9.61 \%)$ cases. Other important reasons for referrals consisted of retinal disorders in 64 (7.99\%), for diagnostic confirmation, follow-up and/or glaucoma treatment in $54(6.74 \%)$ and for corneal disorders in $10(1.25 \%)$.

\section{Cataract surgery outcomes}

Fifty-four $(6.74 \%)$ of the 801 elderly examined had been previously submitted to cataract surgery; 27 in one eye only and 27 in both eyes. The distribution of the 54 patients previously submitted to cataract surgery, according to the classification of vision with the presented and best-corrected VA is shown in table 7.

Of the 54 patients previously submitted to cataract surgery, 2 had severe bilateral blindness even with the best optical correction, and 3 who formerly had moderate bilateral blindness moved to less severe visual categories, after the best optical correction. The main causes of blindness in these cata-

\begin{tabular}{|c|c|c|c|c|c|c|}
\hline $\begin{array}{l}\text { Vision } \\
\text { categories }\end{array}$ & $\begin{array}{c}\text { Normal or } \\
\text { near normal }\end{array}$ & $\begin{array}{l}\text { Uni or bilateral } \\
\text { visual impairment }\end{array}$ & $\begin{array}{l}\text { Unilateral } \\
\text { blindness }\end{array}$ & $\begin{array}{l}\text { Moderate bilateral } \\
\text { blindness }\end{array}$ & $\begin{array}{l}\text { Severe bilateral } \\
\text { blindness }\end{array}$ & Total (Pres. VA) \\
\hline NN & $516(64.6 \%[61.2 ; 68.0])$ & - & - & - & - & $516(64.6 \%[61.1 ; 67.9])$ \\
\hline V Imp & $111(13.9 \%[11.6 ; 16.5])$ & $82(10.3 \%[8.3 ; 12.6])$ & - & - & - & $193(24.2 \%[21.2 ; 27.3])$ \\
\hline U Blind & $4(0.50 \%[0.1 ; 1.3])$ & $20(2.5 \%[1.5 ; 3.8])$ & $47(13.9 \%[11.6 ; 16.5])$ & - & - & $71(8.9 \%[7.0 ; 11.0])$ \\
\hline M Blind & $1(0.1 \%[0.0 ; 0.7])$ & - & $5(0.6 \%[0.2 ; 1.5])$ & $2(0.3 \%[0.0 ; 0.9])$ & - & $8(1.0 \%[0.4 ; 1.9])$ \\
\hline S Blind & - & - & $1(0.1 \%[0.0 ; 0.7])$ & - & $10(1.3 \%[0.6 ; 2.3])$ & $11(11.4 \%[0.7 ; 2.5])$ \\
\hline Total (BCVA) & $632(79.1 \%[76.1 ; 81.9])$ & $102(12.8 \%[10.5 ; 15.3)$ & $53(6.6 \%$ [5.0; 8.9]) & $2(0.3 \%[0.0 ; 0.9])$ & $10(1.3 \%[0.6 ; 2.3])$ & 799 \\
\hline
\end{tabular}


250 Prevalence of visual impairment, blindness, ocular disorders and cataract surgery outcomes in low-income elderly from a metropolitan region of São Paulo - Brazil

Table 4. Prevalence of the main causes of visual impairment/blindness according to presented and best-corrected visual acuity

\begin{tabular}{|c|c|c|c|c|c|c|c|c|}
\hline Main causes* & \multicolumn{2}{|c|}{$\begin{array}{l}\text { Visual impairment } \\
\text { Uni or bilateral }\end{array}$} & \multicolumn{2}{|c|}{$\begin{array}{l}\text { Unilateral } \\
\text { blindness }\end{array}$} & \multicolumn{2}{|c|}{$\begin{array}{l}\text { Moderate } \\
\text { blindness }\end{array}$} & \multicolumn{2}{|c|}{$\begin{array}{l}\text { Severe } \\
\text { blindness }\end{array}$} \\
\hline Refractive error & 53.37 & 38.24 & 57.75 & 50.94 & 12.50 & - & - & - \\
\hline Retinal disorders (all) & 15.03 & 22.55 & 32.39 & 37.74 & 37.50 & - & 36.36 & 40.00 \\
\hline AMD & 3.11 & 6.86 & 7.04 & 7.55 & - & - & - & - \\
\hline Diabetic retinopathy & 3.11 & 1.96 & 1.41 & 3.77 & 12.50 & - & 18.18 & 20.00 \\
\hline Glaucoma & 3.11 & 2.94 & 5.63 & 9.43 & 25.00 & 50.00 & 9.09 & 10.00 \\
\hline Optical atrophy & 2.07 & 3.92 & 2.82 & 5.66 & 25.00 & 50.00 & - & - \\
\hline Posterior capsule opacity & 2.07 & 0.98 & 2.82 & 3.77 & - & - & - & - \\
\hline Absence/disorganization of bulb & - & - & 5.63 & 7.55 & - & - & 18.18 & 20.00 \\
\hline Corneal disorders (in the visual axis) & 2.59 & 4.90 & 12.68 & 16.98 & - & - & 9.09 & 10.00 \\
\hline
\end{tabular}

Table 5. Prevalence of ocular disorders in the 1,602 eyes of 801 participants

\begin{tabular}{lrr} 
& N & \multicolumn{1}{c}{$\%$} \\
Refractive error & 1,138 & 71.04 \\
Cataract & 253 & 15.79 \\
Retinal disorders & 96 & 5.99 \\
Glaucoma & 20 & 1.25 \\
Corneal disorders (in the visual axis) & 18 & 1.12 \\
Optic atrophy & 16 & 1.00 \\
Amblyopia & 14 & 0.87 \\
Posterior capsule opacity & 9 & 0.56 \\
Absence/disorganization of bulb & 8 & 0.50 \\
Undetermined & 14 & 0.87 \\
No visual impairment & 16 & 1.00 \\
Total & 1,602 & 100.00 \\
AMD=25 (1.56\%); DR=20 (1.25\%); Other retinal disorders= 51 (3.18\%) \\
\hline
\end{tabular}

ract-operated eyes (with the best optical correction) are shown in table 8. It was observed that corneal edema was the most prevalent cause, occurring in $4(30.77 \%)$ of the operated eyes classified as blind.

\section{DISCUSSION}

Although the conducted epidemiologic study has not utilized an ideal resident-based sampling, some variables may be used to compare the elderly population resident in the area to the one selected for the study. As the response rate was low among those randomly drawn from senior groups list, and in order to avoid any systematic bias in the selection of the remaining $2 / 3$ of the sample, we chose to select the participants from all the RCE's lists of appointments scheduled for five different days and hours of the week, including those listed in non-medical activities - recreational activities such as arts and crafts, dance, music etc.

The age distribution found in the total sample is comparable to the elderly population in the studied administrative districts, i.e., $61.3 \%$ under 70 years of age ${ }^{(13)}$ versus the $60.42 \%$ found in the present study, for this same age range. As to gender distribution, there was a higher representation of women $(74.28 \%$ vs. $57.8 \%$ ). This is a common phenomenon in field surveys, as they depend on the attendance at institutions and on the compliance with proposals for interviews and clinical examinations. Some possible factors for this unbalanced gender distribution could be a greater participation of women in community groups and their higher life expectancy ${ }^{(14-15)}$.

The lack of standardization for the VA classification criteria and the difference in the studied sample composition contribute to the prevalence disparities in different studies, which follow the current criteria of presented VA and BCVA, unlike others which have used only presented $\mathrm{VA}^{(9)}$ or pinhole acuity ${ }^{(16-18)}$. A major aspect is the classification of vision in more representative categories, so as not to underestimate the results ${ }^{(16,19-22)}$. It is important to point out that the classification used in this study considered bilateral visual condition, therefore classifying the vision condition per individual and not only per each eye. Eleven (1.38\%) with presented VA were included in severe bilateral blindness criteria; after optical correction, however, the number decreased to $10(1.25 \%)$.

Cataract was the main cause of severe bilateral blindness in $30.00 \%$ of the cases, a much lower rate than the almost $60 \%$ estimated for South America ${ }^{(11)}$. Retinal disorders were important as well and were found in 5.99\% of the cases, representing the third major cause of unilateral blindness among visually impaired individuals. It has also been the second major cause for referral to the tertiary service in 64 cases. Furthermore, there were 2 cases of severe bilateral blindness due to diabetic 
retinopathy in our study, as well as 2 others due to other retinal causes. Unlike international reports of industrialized countries with a predominantly Caucasian and Latino populations $^{(23-26)}$ in the present study AMD was not considered as one of the main causes of blindness and these findings are in line with other Brazilian studies ${ }^{(8-9)}$.

We found one case of severe bilateral blindness due to glaucoma. In spite of the difficulty to diagnose this disease, it also proved to be responsible for 11 of the 130 blind eyes. However, this figure might have been underestimated, as there were 54 referrals for the tertiary medical service for glaucoma suspicion. There is much controversy about diagnostic parameters for glaucoma, mainly how to detect its initial stages,

\begin{tabular}{|lcr|}
\hline \multicolumn{3}{|c|}{$\begin{array}{c}\text { Table 6. Distribution of the causes of tertiary assistance at UNIFESP } \\
\text { to the } \mathbf{8 0 1} \text { participants }\end{array}$} \\
Causes of referral & $\mathbf{N}$ & $\%$ \\
Cataract surgery & 77 & 9.61 \\
Retinal diseases & 64 & 7.99 \\
Glaucoma or suspicion of this disease & 54 & 6.74 \\
Corneal disorders (in the visual axis) & 10 & 1.25 \\
Disorders of optic disc & 7 & 0.87 \\
Posterior capsule opacity & 7 & 0.87 \\
Eyelid disorders & 3 & 0.37 \\
Contact lens (unilateral aphakia) & 1 & 0.12 \\
Subtotal & 223 & 27.84 \\
Total & 801 & 100.00 \\
\hline
\end{tabular}

\begin{tabular}{|c|c|c|c|c|}
\hline \multirow[t]{2}{*}{ Classification of vision } & \multicolumn{2}{|c|}{ Presented VA } & \multicolumn{2}{|c|}{ Best correction } \\
\hline & $\mathbf{N}$ & $\%$ & $\mathbf{N}$ & $\%$ \\
\hline Normal or near normal & 15 & 27.78 & 19 & 35.19 \\
\hline $\begin{array}{l}\text { Unilateral or bilateral } \\
\text { visual impairment }\end{array}$ & 20 & 37.04 & 19 & 35.19 \\
\hline Unilateral blindness & 14 & 25.93 & 14 & 25.93 \\
\hline Moderate blindness & 3 & 5.56 & - & 0.00 \\
\hline Severe blindness & 2 & 3.70 & 2 & 3.70 \\
\hline Total & 54 & 100.00 & 54 & 100.00 \\
\hline
\end{tabular}

since intraocular pressure (IOP) measurement by itself is not sufficient ${ }^{(27)}$. Criteria used in the present study went beyond the IOP, taking into consideration also cup/disc ratio $(\mathrm{CDR}) \geq 0.7$ and interocular asymmetry $\geq 0.2$ in CDR, neuroretinal rim width reduced to $\leq 0.1 \mathrm{CDR}$ and/or peripapillary hemorrhage ${ }^{(28-29)}$.

Prevalence of unilateral or bilateral impairment found in the present study was $24.16 \%$, with significant reduction to $12.77 \%$, after the best optical correction. Data collected from 74 "Cataract-Free Zone" projects in the Campinas area and neighboring towns in the state of São Paulo, in individuals aged 50 and over showed uncorrected refractive errors (47.5\%), followed by cataract $(23.6 \%)$ as the main causes of visual impairment ${ }^{(9)}$.

Surgical cataract technique used may impact on visual results $^{(19,21-22)}$. In the present study, 54 participants were previously submitted to extracapsular extraction or to crystalline lens phacoemulsification. Nevertheless, only $27.78 \%$ of those had normal or near normal presented VA. In addition, 13 (16.05\%) of the 81 operated eyes (BCVA) remained blind due to surgical complications. In more than half of these surgical complication cases, the main cause found (30.77\%) was bullous keratopathy. A possible cornea transplant might contribute to the reversion of this blinding condition. Other 2 (15.38\%) exhibited vision improvement after capsulotomy.

Besides investing in the reduction and prevention of the main causes of blindness and visual impairment, it is always necessary to strive for better quality of surgical techniques as well as extended postsurgical monitoring in order to achieve good visual results, thus eliminating the recurrence of visual impairment condition or of blindness among individuals submitted to cataract surgery ${ }^{(9,22,30)}$.

Even with the best optical correction, only about $35.19 \%$ of those subjects presented normal or near normal VA. This fact suggests the undertaking of larger studies, with greater sampling, in order to determine the actual influence of the technical quality of cataract surgery for this population.

\section{CONCLUSION}

Initiatives such as provision of eyeglasses free of charge or carrying out permanent actions for assisting cataract and

\begin{tabular}{|c|c|c|c|c|c|c|}
\hline \multirow[t]{2}{*}{ Main cause } & \multicolumn{2}{|c|}{ Bilateral blindness } & \multicolumn{2}{|c|}{ Unilateral blindness } & \multicolumn{2}{|c|}{ All blind eyes } \\
\hline & $\mathbf{N}$ & $\%$ & $\mathbf{N}$ & $\%$ & $\bar{N}$ & $\%$ \\
\hline Corneal edema after cataract surgery & & - & 4 & 44.44 & 4 & 30.77 \\
\hline Diabetic retinopathy & 2 & 50.00 & - & - & 2 & 15.38 \\
\hline Absence/disorganization of bulb & 2 & 50.00 & - & - & 2 & 15.38 \\
\hline Posterior capsule opacity & & & 2 & 22.22 & 2 & 15.38 \\
\hline Optic atrophy & & - & 1 & 11.11 & 1 & 7.69 \\
\hline Corneal opacity & & & 1 & 11.11 & 1 & 7.69 \\
\hline Macular hole & & - & 1 & 11.11 & 1 & 7.69 \\
\hline Total & 4 & 100.00 & 9 & 100.00 & 13 & 100.00 \\
\hline
\end{tabular}


252 Prevalence of visual impairment, blindness, ocular disorders and cataract surgery outcomes in low-income elderly

from a metropolitan region of São Paulo - Brazil

diabetic retinopathy patients are fundamental to fight reversible causes of blindness in the elderly. The results obtained in this research project led to the necessary guidelines in ophthalmology for that specific region. Data were presented in a technical report to the DSTTED and served as basis for the implementation of the Ophthalmology Service at the Prof. Alípio Correa Neto Town Hospital (Ermelino Matarazzo Hospital) forming a partnership between the Institute of Vision UNIFESP, Health Administration of the City of São Paulo and Lions Club International. This service started in the year 2003, and provides greater complexity ophthalmic procedures in that hospital.

\section{RESUMO}

Objetivo: Determinar a prevalência e causas de deficiência visual, cegueira além dos resultados de cirurgia de catarata numa população idosa de baixa renda de São Miguel Paulista, distrito da cidade de São Paulo. Métodos: Estudo observacional no qual a acuidade visual apresentada e com a melhor correção óptica foi medida em 801 indivíduos com 60 anos ou mais anos, bem como realizado exame oftalmológico. Definição de cegueira e deficiência visual seguiu estudos prévios realizados no Nepal, China e Índia. Resultados: As prevalências de acuidade visual apresentada e com a melhor correção óptica pior do que 20/400 em ambos os olhos foram $1,38 \%$ (intervalo de confiança de 95\%: $0,69 \%-2,45 \%$ ) e $1,25 \%$ (intervalo de confiança de $95 \%: 0,60 \%-2,29 \%$ ). As de deficiência visual considerando a acuidade visual apresentada e com a melhor correção óptica foram, respectivamente, $24,16 \%$ (intervalo de confiança de $95 \%: 21,22 \%-27,28 \%$ ) e 12,77\% (intervalo de confiança de 95\%: 10,53\% - 15,28\%). Catarata foi a principal causa de cegueira $(30,00 \%)$ e deficiência visual $(54,90 \%)$. Cirurgia prévia de catarata foi realizada em 54 participantes $(6,74 \%)$ e $35,12 \%$ mostraram acuidade visual com a melhor correção óptica melhor do que 20/60 em ambos os olhos. Houve considerável diminuição nas prevalências de deficiência visual e cegueira após a correção óptica. Conclusão: Catarata foi a principal causa de cegueira. Os resultados visuais ruins nos olhos operados reforçam a necessidade de serviços de boa qualidade e de seguimento pós-operatório cuidadoso.

Descritores: Cegueira/epidemiologia; Transtornos da visão/ epidemiologia; Erros de refração/epidemiologia; Catarata/epidemiologia; Idosos; Brasil

\section{REFERENCES}

1. Resnikoff S, Pascolini D, Etya'ale DD, Kocur I, Pararajasegaram R, Pokharel GP, et al. Global data on visual impairment in the year 2002. Bull World Health Organ. 2004;82(11):844-51.

2. Dandona R, Dandona L. Socioeconomic status and blindness. Br J Ophthalmol. 2001;85(12)1484-8.

3. Ramos LR, Toniolo J, Cendoroglo MS, Garcia JT, Najas MS, Perracini M, et al. Two-year follow-up study of elderly residents in S. Paulo, Brazil: methodology and preliminary results. Rev Saúde Pública. 1998;3(5)2:397-407.

4. West S, Sommer A. Prevention of blindness and priorities for the future. Bull World Health Organ. 2001;79(3):244-8. Comment in: Bull World Health Organ. 2002;80(5):419.

5. Baltussen R, Sylla M, Mariotti S. Cost-effectiveness analysis of cataract surgery: a global and regional analysis. Bull World Health Organ. 2004;82(5): $338-45$.

6. Pararajasegaram R. VISION 2020 - the right to sight: from strategies to action. Am J Ophthalmol. 1999;128(3):359-60. Comment in: Am J Ophthalmol. 1999; 128(3):357-8

7. World Health Organization. Sight test and glasses could dramatically improve the lives of 150 million people with poor vision. [text on the Internet]. Geneva: WHO; 2006. [cited 2006 Oct 11]. Available from: 1. http://www.who.int/ mediacentre/news/releases/2006/pr55/en/index.html

8. Esteves JF, Domingues CG, Borges LP, Skolaude PB, Bortolomiol L, Muxfeldt R, et al. Prevalência e causas de cegueira em bairro de Porto Alegre. Arq Bras Oftalmol. 1996;59(3):244-7.

9. Arieta EL, Delgado AM, Jose NK, Temporini ER, Alves MR, Moreira Filho DC. Refractive errors and cataract as causes of visual impairment in Brazil. Ophthalmic Epidemiol. 2003;10(1):15-22.

10. Muñoz B, West SK. Blindness and visual impairment in the Americas and the Caribbean. Br J Ophthalmol. 2002;86(5):498-504.

11. Silva JC, Bateman JB, Contreras F. Eye disease and care in Latin America and the Caribbean. Surv Ophthalmol. 2002;47(3):267-74.

12. Pascolini D, Mariotti SP, Pokharel GP, Pararajasegaram R, Etya'ale D, Negrel AD, et al. 2002 global update of available data on visual impairment: a compilation of population-based prevalence studies. Ophthalmic Epidemiol. 2004;11(2):67-115.

13. Instituto Brasileiro de Geografia e Estatística - IBGE. Projeção da população no Brasil 1980-2050 [texto na Internet]. Rio de Janeiro: IBGE; 2000. [citado 2005 Jun 27]. Disponível em: http://www.ibge.gov.br/home/estatistica/populacao/projecao_da_populacao/default.shtm

14. Instituto Brasileiro de Geografia e Estatística - IBGE. Censo Demográfico 2000: Características da população e dos domicílios: resultados do Universo. [texto na Internet].Rio de Janeiro: IBGE; 2002. [citado 2005 Jan 9]. Disponível em: 2. http://www.ibge.gov.br/home/estatistica/populacao/censo2000/ tabelabrasil111.shtm

15. Aquino EM, Menezes GM, Amoedo GB. Gênero e saúde no Brasil: considerações a partir da Pesquisa Nacional por Amostra de Domicílios. Rev Saúde Pública. 1992;26(3): 195-200.

16. Zhao J, Jia L, Sui R, Ellwein LB. Prevalence of blindness and cataract surgery in Shunyi County, China. Am J Ophthalmol. 1998;126(4):506-14. Comment in: Am J Ophthalmol. 1998;126(4):582-5.

17. Michon JJ, Lau J, Chan WS, Ellwein LB. Prevalence of visual impairment, blindness, and cataract surgery in the Hong Kong elderly. Br J Ophthalmol. 2002;86(2):133-9.

18. Duerksen R, Limburg H, Carron JE, Foster A. Cataract blindness in Paraguay results of a national survey. Ophthalmic Epidemiol. 2003; 10(5):349-57.

19. Pokharel GP, Regmi G, Shrestha SK, Negrel AD, Ellwein LB. Prevalence of blindness and cataract surgery in Nepal. Br J Ophthalmol. 1998;82(6):600-5. Comment in: Br J Ophthalmol. 1998;82(6):593-4.

20. Li S, Xu J, He M, Wu K, Munoz SR, Ellwein LB. A survey of blindness and cataract surgery in Doumen County, China. Ophthalmology. 1999;106(8):1602-8.

21. Murthy GV, Gupta S, Ellwein LB, Munoz SR, Bachani D, Dada VK. A population-based eye survey of older adults in a rural district of Rajasthan: I. Central vision impairment, blindness, and cataract surgery. Ophthalmology. 2001;108(4):679-85.

22. Nirmalan PK, Thulasiraj RD, Maneksha V, Rahmathullah R, Ramakrishnan R, Padmavathi A, et al. A population based eye survey of older adults in Tirunelveli district of south India: blindness, cataract surgery, and visual outcomes. Br J Ophthalmol. 2002;86(5):505-12.

23. Attebo K, Mitchell P, Smith W. Visual acuity and the causes of visual loss in Australia. The Blue Mountains Eye Study. Ophthalmology. 1996;103(3):357-64.

24. Muñoz B, West SK, Rubin GS, Schein OD, Quigley HA, Bressler SB, et al. Causes of blindness and visual impairment in a population of older Americans: The Salisbury Eye Evaluation Study. Arch Ophthalmol. 2000;118(6): 819-25.

25. Buch H, Vinding T, La Cour M, Appleyard M, Jensen GB, Nielsen NV. Prevalence and causes of visual impairment and blindness among 9980 Scandinavian adults: the Copenhagen City Eye Study. Ophthalmology. 2004;111(1):53-61.

26. Varma R, Ying-Lai M, Klein R, Azen SP; Los Angeles Latino Eye Study Group. Prevalence and risk indicators of visual impairment and blindness in Latinos: the Los Angeles Latino Eye Study. Ophthalmology. 2004;111(6):1132-40.

27. Varma R, Ying-Lai M, Francis BA, Nguyen BB, Deneen J, Wilson MR, et 
al. Prevalence of Open-angle glaucoma and ocular hypertension in Latinos: the Los Angeles Latino Eye Study. Ophthalmology. 2004;111(8):1439-48. Comment in: Ophthalmology. 2005;112(4):733; author reply 733-4.

28. Weih LM, Nanjan M, McCarty CA, Taylor HR. Prevalence and predictors of open-angle glaucoma: results from the visual impairment project. Ophthalmology. 2001;108(11):1966-72.
29. Foster PJ, Buhrmann R, Quigley HA, Johnson GJ. The definition and classification of glaucoma in prevalence surveys. Br J Ophthalmol. 2002; 86(2):238-42.

30. De Senne FM, Cardillo JA, Rocha EM, Kara-Jose N. Long-term visual outcomes in the Cataract-Free Zone Project in Brazil. Acta Ophthalmol Scand. 2002;80(3):262-6. 